\title{
The Davidic covenant in 1 and 2 Chronicles: A new theme for an old song
}

\author{
H.W. Nel \\ Department of Old Testament \\ University of South Africa \\ PRETORIA
}

\begin{abstract}
It is impossible to reach ultimate finality or consensus concerning any Old Testament book. This study represents an attempt to come 10 grips with the controversies surrounding $l$ and 2 Chronicles. In an attempt to determine the reason(s) for the ongoing and the never-ending debate concerning the historical accuracy, the date, the authorship and the identity of the socalled (hronicler, a study has been made of the historically true picture of the historic period or the date of origin usually ascribed to this work, namely the final days of the Persian Empire. In the second place the manner in which a picture of the Davidic history is presented by this book, has been studied in conjunction with but one of the theologies discernible in 1 and 2 Chronicles, namely that of creation and re-creation (in the sense of formation and re-formation renewal) and election and re-election. The outcome of this study has resulted in the formulation of the hypothesis presented in this paper, namely that the origin of the confusion surrounding 1 and 2 Chronicles should be sought in the fact that time has relegated to oblivion the method by which this work was created, namely that of midrash or group exegesis which evolved during the so-called Kallah months or the months of assembly, namely Adar and Elul. During these months all men assembled to discuss matters of mutual importance pertaining to the past, the present, and especially to the re-institution of their own norms and values in the yet unknown future. (In this study the Biblia Hebraica Stuttgartensia (1984) formed the main literary source.)
\end{abstract}

\section{Introduction}

\subsection{General}

To a far greater extent than any other book in the Old Testament, 1 and 2 Chronicles appear to present to the superficial reader as well as to the scholar, a myrad of faces. The result of this frustrating confusion is even greater confusion, because this apparent mayhem has (and will continue to do so) provided scholars 
and students with the irresistable opportunity to ascribe a multitude of divergent and related aims to the author/authors of this work. In Chronicles historical facts manage to manifest in many different ways; therefore the continual attempts of eminent scholars earlier even as De Wette (1806/1971) and Torrey (1896: 51-65), to account for this multi-faceted presentation of history, have so far been to no avail. In fact, in their desire for consensus, many scholars have only succeeded in experiencing variety as confusion.

Japhet avers in her book The Ideology of the Book of Chronicles and Its Place in Biblical Thought (1989b:2-8), that the emphasis of the research on Chronicles has reverted from a historical true picture to a picture of history, and in order to understand the spiritual world of the Chronicler, the work should be examined on its own terms without any attempt to harmonize it with any predetermined ideological structure. With reference to this pronouncement of Japhet, the multifaceted manifestation of history and the ensuing confusion, the premise of this paper is that the picture of history, the historical true picture and the ideologies and/or theologies presented by Chronicles, are confusing only because in the course of time they have become artificially integrated and interlocked when the method or system by which this work was originally developed, was relegated to the oblivion of forgotten history.

\section{The historical true picture, a picture of history and an ideology}

\subsection{General}

According to my operational approach, 1 and 2 Chronicles represent the results of exegetical conclusions of group exegetical debates which had their embryonic beginnings during the so-called Kallah month discourses that originated in exile. While the postulate is that the compilation of this work should be understood as an on-going process, yet undoubtedly certain periods in time inspired a greater effort to plot the future in terms of the past: perhaps during the decline of the Persian Empire or even during the height of the Hasmonean empire. Other periods (for instance during the height of Persian rule) demanded the need to adopt and to fuse certain aspects of colonial rule with traditional folk rule and in this respect 1 Chronicles 23-26 is an excellent example.

Therefore, should the many-sided and often conflicting historical picture of the declining years of the Persian Empire be taken as that point in history when it was considered essential to conclusively interpret the past in terms of future secular leadership, then the historical true picture at that particular moment in time of the Persian colony Yehud, becomes of paramount importance

According to Albright (1934:21) and Finkelstein (1974:72-76) inter alia the district of Judah or Yehud formed part of the Persian satrapy west of the Euphrates 
as a separate administrative unit with an autonomous internal administration. Yeluud consisted of Jerusalem and the strip of surrounding land approximately forty six kilometers by thirty two kilometers and was governed by a Persian governor. Albeit a preference for the local priesthood instead of the indigenous military aristocracy formed part and parcel of Persian foreign policy, the nobles of the Jews (the heads or leaders of families, clans, tribes) represented the Jews at the governor's court

Despite attempts to depict the post-exilic Judaean community as an exclusive group of people who approached every aspect of their lives from a religious point of view, scholars like Finkelstein (1974:77-79) inter alia aver that the Jews of the Restoration period, like every other generation at every other point in history, were entangled in and confronted by a web of contradictions and conflicting patterns of real life. It is difficult to ascertain whether these Jews were satisfied with the role of the cultic officialdom which the Persian bureaucracy favoured, or whether they were aggressively preparing for a speedy resurrection of the old Davidic monarchy in the aftermath of the collapse of the Persian empire. However, without any doubt 1 and 2 Chronicles' interpretive ideological picture of history reflects the historical true picture as well as all the confused thoughts, feelings and expectations of the people of Yehud at certain moments in their history, intricately interwoven with a concen for the future. According to this postulate 1 and 2 Chronicles represent the result of ideological futuristic exegetical discussions of various groups over an unknown period of time, but discussions which actually commenced during the Kallah month assemblies while still in exile. It is this intricate picture which have been causing mayhem among scholars for very many centuries.

\subsection{The Kallah month system}

According to Kravitz (1973:194) the so-called Kallah month discourse system initiated during the exile, entailing the assembly of all men (students and common people alike) during the months of Adar before Passover and Elul before Rosh Hashanah in order to discuss issues of crucial importance to the community. There is no suggestion that it was a prerequisite that the same group of men should or would automatically meet on every occasion. Because of the changing fellowship of these meetings, every debate reflect the views, the feelings and the ideologies of that unique group of interested men who, at a particular moment in history, discussed a certain issue(s). At the same time their own varied experiences of the past and their expectations of the future would of necessity influence a group's interpretation of history at the moment of their meeting. While this variety in interpretation and expectation, in ideology and theology, caused the development of the bias concening reliability, it also became the principal force in the debate concerning the many inferred discrepancies and/or secondary insertions. 


\subsection{The selection and the interpretation of traditions and traditional themes in history}

While it is accepted that 1 and 2 Chronicles like all other Bible manuscripts, suffered different kinds and degrees of amendments at different points in time after the original, albeit unknown date of composition, it is evident from the version currently extant, that the power vested in the antecedence of traditions (Kegler, \& Augustin, 1984; Nel, 1991; 1992:342-357) was greatly valued in the compilation of this book, primarily because of the firm, yet instinctive belief that traditions imply experiential truths (cf. Knight, 1990:174-276). This interpretive and selective use of particular historical traditions resulted in the development of a number of diverse recurring themes within an all-encompassing principal motif of a theocratic rule. Furthermore, it is clear that these exegetes regarded a theocratic form of government as the only feasible polity with the inherent strength and adaptability able to guarantee the re-institution as well as the continued survival of the Southem Kingdom. While passages like 1 Chronicles 23-26 inter alia suggest that at certain moments in time a change in circumstances caused other themes and sub-themes to be considered as being of equal or of greater importance, unquestionably the most crucial of these recurring themes concern the continuous re-affirmation of the original covenant between God and the Davidites on the one hand and between the Davidites and the non-cultic and non-regal people on the other hand. At the same time the Davidic covenant as well as the monarchal history was expected to re-affirm the manner in which this covenant was embedded within a theology of creation and re-creation, election and re-election. The all-embracing major theme identifiable in 1 and 2 Chronicles is, therefore, God's creative activity (cf. in particular 1 Chr. 1:1-9:1, 2 Chr. 36:22-23) bonded within a secular polity of theocratic rule.

\subsection{A polity and a theology}

According to 1 and 2 Chronicles a theocracy or a rule of God infers two core components, namely the God who rules and a people who is ruled (Nel, 1991). While God is the constant core component, unique, unchangeable, the chosen people, the second core component, consist of three integrated, yet separate, elements: secular leadership, cultic leadership and the non-regal non-cultic people (from now on referred to as the Benjaminites).

Because there can be no theocracy without God as ruler and without a people to be ruled, all the identifiable recurring themes and/or sub-themes revolve around and/or form an integral part of an idealistic image of a future post-exilic society re-established within that particular land promised to the patriarchs and ruled by a scion of the original David at the behest of God (cf. inter alia Williamson, 1977: 130-131, also Wifall, 1974:95-107). 
Although Chronicles, P, Ezra and Nehemiah, all demonstrate a concern for the need to define the community (cf. Williamson, 1977:132 inter alia), Chronicles contain certain presuppositions concerning the formation and the structuring of a people and of a state all revolving around one main theme: God who is universal created all people. All twelve tribes, therefore, were from the beginning, still are and always will form an integral part of lsrael. However, an inherent part of God's eternal and unceasing acts of formation (creation) and renewal (re-creation) is his infinite ability to elect and to re-elect without ever renouncing or relinquishing any minute part of his own creation. Therefore, the men and the women of the Southern Kingdom are his chosen people (cf. in particular 1 Chronicles (-9). Within this concept, Chosen People, the Kallah exegetes have incorporated their most crucial perspectives of the creative and re-creative aspects of God's Being and of his activities in general. Therefore, the theology elucidated in this work, presents an internittent pattem of creation, renewal and election (cf. Nel, 1991:46-47):

God creates universally $>$ God elects Abraham and his descendants $>$ God creates/forns the Abraham tribe $>$ God elects Jacob/lsrael and his descendants > God creates/forms All Israel > God elects three tribes to fulfil three diverse, yet integrated functions $>$ God elects one of his creatures, namely Cyrus, to re-establish the post-exilic core of returnees from the ranks of which God would eventually re-create/re-form his Chosen People.

\subsection{The core component Chosen People}

In Chronicles all recurring themes and sub-themes concerning the core component, Chosen People, revolve around an idealistic image of the construction of a model society. According to 1 and 2 Chronicles God rules his chosen People who can only function as a nation should there be an integrated interaction of the three different elements that constitute this core component: secular leadership, cult and cult officials and the non-cultic, non-regal people governed and directed by secular and sacral leadership. Cf. Nel (1991:63-65) who explains this concept diagrammatically as follows:

Diagram 1: Chosen People

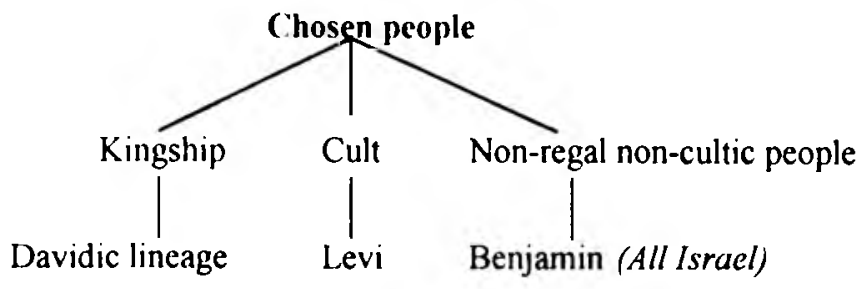


An important aspect of this work is that the word creation is never mentioned (cf. Biblia Hebraica Stuttgartensia, 1984), yet the creative and the re-creative aspects of the Being of God form an implicit component of 1 Chronicles 1:1-7:40, especially when God is portrayed as the Creator-God of all humankind. 1 Chronicles 1:1-9:1 read in conjunction with 2 Chronicles 36:22-23 constitute an allencompassing framework of continuous formation/creation and renewal/recreation, election and re-election. The result of this presentation is a selective interpretive version of particular aspects of the monarchal history of the Davidites and their era.

God is portrayed as the Creator-God who is constantly engaged in the neverending act of formation/creation, re-formation/re-creation, election and re-election, yet in Chronicles the triad election, formation/creation, re-creation/renewal are not understood as unique or isolated acts of God, but they form an integral part of the quintessence of God. The concept all Israel or כלידיטראל Delineates the distinctiveness and diversity of a nation, but at the same time the genealogies introduced by Adam emphasize the universality of God as the Creator-God. The creative and the elective aspects of the Being of God are emphasized by the use of particular nomenclature like children of God, all Israel, Israel.

According to Chronicles' version of the creation of humankind and nationhood in 1 Chronicles 1:1-9:1, the inherent universality of God's creative abilities is embodied within Adam. Therefore, 2 Chronicles 36:22-23 forms an apt ending when God employs one of his creatures, albeit not one of his Chosen People, to re-form/re-create the people and the land of Judah. This highly interpretive rendition of the tradition according to which the nation of the Southern Kingdom comprised in essence three of the twelve major tribes of Israel (Judah, Levi, Benjamin cf. 1 Chr. $2: 3-4: 23 ; 6 ; 8$ ) should not, however, be regarded as a mere repetition of facts. Neither is it a true picture of history. It is, in fact, the exposition of a unique theology implying that according to God's choice, every tribe should fulfil a particular pre-determined role, a defined function, within the context of the newly created People or nation of the Southern Kingdom:

- $\quad$ The tribe of Judah represents Davidic kingship (1 Chr. 5:2).

- The tribe of Levi represents the cult and cultic leadership (1 Chr. 6).

- The tribe of Benjamin ( $1 \mathrm{Chr} .8$ ) represents the collective non-regal and non-priestly element of the core component Chosen People.

Three individual tribes, Judah, Levi and Benjamin, are therefore responsible for all the social requirements and for all the essential societal functions within any nation, namely:

- state leadership,

- religion and religious leadership, 
- a people governed by the state as well as by the cult.

These individual functions are complementary and ancillary and cover the complete spectrum of national life; therefore they do not overlap. By means of their independent yet completive tribal functions, the different tribes form a nation when the act of election unites them into an integrated full-fledged nation, namely the Chosen People of the Southern Kingdom, the second core component of the theocratic rule instituted by God during his initial act of Creation.

However, in 1 and 2 Chronicles the concept Chosen People embodies a dichotomy: religious and political. Politically, preference is given to a monarchy, but within an all-encompassing theocratic rule the definitive interpretation of the meaning of the concept nation also comprises the formation of a sublime gathering of chosen people. In this interpretive view of the Davidic dynasty as a theocracy, the two core components are so intricately interrelated and integrated, that the envisaged restoration of the Southern Kingdom manifests as the re-establishing or the re-creative power of God.

\section{Davidic kingship, an element of the core component Chosen People, as a norm of excellence and of future conduct}

\subsection{General}

While in the northern kingdom of Samaria different dynasties ruled at various points in time, the southem kingdom of Judah knew only the Davidic dynasty, except for a very brief period of time when the usurper Athalia ruled $(2 \mathrm{Chr}$. $22: 9 b-23: 21$ ). As a result the monarchal office and the person of the monarch became inextricably intertwined in the reasoning of the assembled men of Judah (cf. inter alia 1 Chr. $2: 3-4: 23 ; 5: 2$ ). The importance of Davidic secular leadership is underlined by the fact that most of the genealogies in 1 Chronicles 1-9 refer to the tribe of Judah to which the Davidic dynasty belonged. Should 1 Chronicles 2:3$4: 23$ reflect a true post-exilic tradition, it endorses Wifall's (1974:95-107) theory that in post-exilic times the Davidic lineage was still deemed essential in order to be accepted as a legitimate leader of the people. Wifall's theory not only serves as an explanation of the role of the post-exilic Davidites in Judah, it also provides us with a possible explanation for the Chronicler's unique interpretive use of the role of the Davidic kings as a paradigm for secular leadership integrated with a theology of formation/creation and renewal/re-creation, election and re-election (cf. inter alia 1 Chr. $1: 34 ; 2: 1-55$ ).

\subsection{God and monarch; monarch and God}

According to certain scholars (Noordtzij, 1954:43-47; Roubos, 1983:11-12) 1 and 2 Chronicles meant to impress upon the people that Davidic kingship should 
form the cardinal norm by means of which all past, present and future national leaders ought to be evaluated. This unique interpretation of the monarchal history of the Southern Kingdom transformed Davidic kingship into a historical paradigm to measure, sanction and to legalize contemporary leaders and their endeavours to restore the community within the purview of what the exegetes regarded as the only ideal, yet viable polity, namely the theocracy.

Therefore, although the monarchal history of 1 and 2 Chronicles is enacted against the background of a historical framework, the picture of history suggested by the interpretive narration of certain events and of the biographies of certain of the Davidic kings, often deviates from the Deuteronomic version. While inter alia 1 Chronicles 1:1-6:53; 7:1-9:44; 12; 22-29, 2 Chronicles 14:2-7; 16:19; 16:7-10; $17: 1619 ; 19: 4-23: 21 ; 29: 1-31: 12 ; 33: 14-17$, are all unique to 1 and 2 Chronicles, the following passages are missing: 1 Samuel 9-30; 2 Samuel 1-3:1; 3:6-4:12;9; $12: 25 ; 13: 2-20: 22 ; 21: 1-14 ; 22: 1-23: 7$; 1 Kings $1: 1-3: 1 ; 3: 16-4: 34 ; 7: 1-12 ; 8: 54-$ $66 ; 11: 1-4 ; 12: 25-14: 20 ; 15: 25-21: 29 ; 22: 52-54 ; 2$ Kings $1: 1-8: 15 ; 9: 1-10: 36$; $12: 17-18 ; 13 ; 14 ; 17: 2-9 ; 15: 8-31 ; 17 ; 18: 9-12 ; 25: 22-29$.

Old Testament scholars concur that the Chronicler and the Deuteronomist represent divergent perspectives regarding kingship. While the Deuteronomist bears witness of the existence of divergent contra-distinctive monarchal traditions within Israel (Judg. 8:23, 9:6-56, 1 Sam. 8 concerning an anti-monarchal tradition and inter alia 1 Sam. 16:1 advocating a pro-monarchal tradition), Chronicles expresses no evidence whatsoever of this struggle or any awareness of the existence of this discord. It would appear as if the Chronicler regarded this conflict as having been satisfactorily concluded in pre-exilic times and therefore it was no longer of any consequence.

In Chronicles the hopes for the future are based upon the experiences of the past (Roubos, 1983:14); therefore the history of the core component Elect People is wielded like an instrument to sanction the present and to secure the future. To fulfil this objective, historical facts are often ignored or re-interpreted when they do not conform to certain views or they are regarded as detrimental to any of the elements of the core component Chosen People (inter alia the history of Judah and Tamar and of David and Bathsheba; the role of Benaiah in the founding of the Solomonic kingdom; Solomon's numerous foreign wives, etc).

Therefore, even though the interpretation of the Davidic monarchy portends to depend upon true historical data, the assembly of exegetes' unique employment of historiography characterizes them primarily as ideologists and only thereafter as historians, and then only as interpreters of a particular history. Because of their pro-Davidic ideological interpretation of history by means of a particular theology, the pre-exilic Davidic monarchs were stripped of their humanity and turned into paradigms of good and bad rulers, but always within an all-embracing theological structure of continuous renewal and new beginnings. It is, therefore, 
unnecessary to predetermine an ideological structure or an ideological struggle in 1 and 2 Chronicles. Ideology forms an inherent and an intrinsic part of this book.

\subsection{Evaluative criteria}

The Kallah month exegetes formulated and applied various criteria to critically evaluate the various Davidic kings and their deeds, inter alia diverse rhetorical formulae concerning the royal lifestyle and the manner and place of royal burials (Nel, 1991:74-79). These rhetorical evaluative formulae should be seen as representative of the perspectives, of the interpretive and evaluative abilities of that particular group of men who assembled to judge and to weigh the quality of reign and the personal rapport of every Davidic monarch with God. Their interpretation of the interminable cycle of birth, coronation and death of the various Davidic kings emphasizes the exegetes' concept of the unceasing and eternally creative and re-creative acts of God.

Furthermore, the aim of these exegetes' unique evaluative interpretation of the monarchal history of the Southern Kingdom, was of a dichotomous nature. In the first instance the community, depleted and drained of national pride and the belief in an independent future, had to be empowered with the assurance that a return to the same degree of greatness as enjoyed under the original David, need not remain a dream. What once has been, can and always will be re-newed, re-instituted, re-created. However, to achieve this ideal situation there is an important pre-condition: the Chosen People should at all costs and in all ways follow the precepts of David, the first veritable theocratic ruler. Yet, at the same time it is imperative that the vicissitudes of David-Solomon's unfaithful successors are not forgotten.

\subsection{The David-Solomon period}

In their employment of the past to provide for the future, these exegetes divided the Davidic dynasty into two distinct poles or phases:

- The David-Solomon period.

- The other Davidites.

David and Solomon are never judged, never evaluated. In their midrash or exegesis of the careers of these two historical figures, the exegetes fused and integrated the histories of the two monarchs into a monolithic unit with David as the designing and Solomon as the executive partner of this duo. As a result, although they became completely dehumanized, yet they are presented as the epitome of the ideal theocratic monarch or secular leader, the only veritable norm of excellence considered acceptable. 
In this unique exposition of the Davidic monarchy, David-Solomon's fused rule becomes the commencement par excellence of the immaculate theocratic rule. Yet, in the only reference to Solomon's single independent act, namely his decision concerning the situation of a palace for the daughter of the pharaoh ( 2 Chr. 8:11), there is a disguised warning: even within the unblemished there is an inherent albeit latent possibility of digression and deviation.

By means of evaluative formulae the remainder of the Davidic kings are divided into the following categories:

- Monarchs who ruled exclusively according to the injunctions of God.

- Monarchs who ruled according to the bidding of God as well as foreign gods or idols.

- Apostate monarchs who rejected God completely.

While continually referring to the standards set by David-Solomon, the history of their successors are interpreted and evaluated according to unambiguous themes, namely election, legitimacy and retribution as part of a theology of formation' creation and renewal/re-creation.

\subsubsection{Legitimacy, election, retribution}

According to 1 Chronicles $1-9$ election forms the crux of legitimacy. God created the monarchal rule and He elected the person of the king as well as the office of kingship and therefore office and office bearer are legitimate and authoritative. However, election and legitimacy do not warrant fidelity, but neither do they exclude punishment. The realization and the admission of transgression and sincere repentance are without fail followed by exoneration. A king may die without repentance and without being exonerated, but his guilt is not transferred to his successor. Without fail the Davidic covenant is reconfirmed with the son's coronation and a re-establishment, a re-creation of the original Davidic monarchy takes place. Therefore, every new king personifies a new beginning, a re-institution of the original Davidic covenant.

\subsection{David-Solomon's successors as paradigms of secular leadership}

\subsubsection{The unremittingly faithful king}

By means of various evaluation formulae the Kallah month exegetes categorized the successors of David-Solomon into three distinct groups: the unremittingly faithful, the partially faithful/unfaithful and the unremittingly unfaithful.

According to 1 and 2 Chronicles, the reigning king's rapport with God undoubtedly determined the type of Godly rule functional at a particular time. In all ca- 
ses, however, the unremittingly faithful Davidic king is considered the immaculate norm of judgment according to the formula:

The king did what was right in the eyes of God and walked in the ways of David his father and he did not turn aside to the right or to the left (inter alia 2 Chr. 34:2).

Although the religious biases of the king determine the influence of God within the society, the people remain dependent upon the rule of God. Within the immaculate relationship there is no leeway for any other god, idol or any other religious item (inter alia $2 \mathrm{Chr}$. 34:3-7). God is the constant core component; $\mathrm{He}$ cannot be obliterated. Re-establishment, re-creation is without fail a certainty whether the theocracy manifests as a hierocracy, a pan-theocracy, an a-theocracy or a democracy.

\subsubsection{The role of the Davidic monarch within a hierocracy}

\section{Diagram 2: The hierocracy}

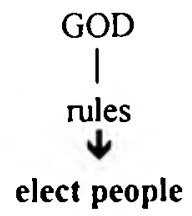

by means of cult official(s) but always in the presence of the reigning Davidic monarch.

During the reign of a number of Davidites, circumstances necessitated the manifestation of the theocracy as a hierocracy. The most appropriate examples in these respects are David-Solomon (1 Chr. 23-26), Hezzekiah (2 Chr. 29-32) and Josiah (2 Chr. 34-35). Even when the theocracy manifests as a hierocracy, the priestly rule may only be executed within the purview of the Davidic monarchy and while a Davidite is purportedly the ruler. The extent of the hierocratic rule always depends upon the person of the monarch and the substance of his faith.

According to 2 Chronicles $8: 14 \mathrm{~b}$ the concept of a hierocratic rule was introduced during the reign of David and from that moment it would remain a dynamic force. In fact, I Chronicles 11:1-3 (the coronation of David in Hebron) corroborates this postulate. 2 Samuel 15-29 (the coup d'etat and the coronation of Absolom) affirms that the nucleus of the hierocratic rule must have existed even before the actual founding of the monarchy (cf. Nel, 1989:257-271 concerning the possible reasons for the establishment of the so-called Levitical cities and their role during the reigns of the various monarchs). 
It could be concluded from a number of incidents which took place during the reigns of various kings, that an ongoing power struggle existed between the $\mathrm{Da}$ vidic monarchs and the hierocracy. Certainly the most noteworthy examples in this respect are the history of the usurper Athaliah (2 Chr. 23) and that of Uzziah ( $2 \mathrm{Chr}$. 26:16-20), because in both instances the hierocratic party triumphed.

Joash's rule ( 2 Chr. 22:10-23:7) was undoubtedly established by means of a hierocracy (2 Chr. 23:1-11). Nevertheless, after the death of his patron, the priest Jehoiadah (2 Chr. 24:15-16), the king attempted to decimate the powers of the hierocracy ( 2 Chr. 24:17-27), but it is doubtful whether he met with any measure of success.

According to 2 Chronicles 29-31 and 2 Chronicles 34-35 Hezzekiah as well as Josiah defied the cult bureaucracy in an attempt to again recoup all forces of government in the hands of the reigning monarch. Although the exegetes maintain their silence, 2 Chronicles 32:24-33 hint at a possible defeat for Hezzekiah. On the other hand, 2 Chronicles 34:32-33 attest to Josiah's resurrection of a consummate theocratic monarchy a la David-Solomon.

\subsubsection{The pan-theocracy}

\section{Diagram 3: The pan-theocracy}

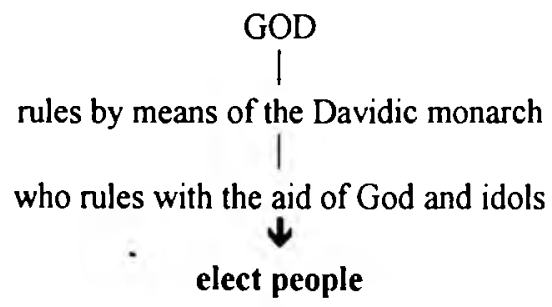

In concurrence with all other forms of theocratic rule, in a pan-theocracy the religious biases of the king determine the influence of God as well as that of the other idols. The monarchy does not attempt to renounce the theocratic rule, yet neither does it function within or outside the parameters of the theocracy.

The significance of a pan-theocracy operating within these parameters, is that the religious disposition of the Davidic monarchs without fail manifest a dichotomous character. The people are ruled by invoking the aid of the God of David-Solomon as well as that of any other god or idol regarded as justifiably acceptable or fashionable at that particular moment in time. In other words, at one point or another in their careers these kings all regarded the gods or objects they idolized as on a par with the God of David-Solomon. Undoubtedly the most outstanding 
example in this respect is Chronicles portrayal of Manasseh's reign (cf. $2 \mathrm{Chr} .33$ : $12-20)$.

2 Chronicles 8:11 (cf. $1 \mathrm{Kn} .11: 1-8$ ) is yet another excellent example of the astute sense of historical data of the Kallah month exegetes. This passage contains an almost imperceptible referral to Solomon's solution regarding the most appropriate location for a palace for the daughter of the pharaoh. True historical data is used to introduce a moot issue affecting the past and the future. This passage unquestionably reflects the first discordant note in the David-Solomon history by insinuating the embryonic commencement of a future form of monarchal theocracy, the pan-theocracy, with the fidelity of the monarch hovering between the only true God of the elect people and the false gods of the infidels: faithful to no one god, yet forswearing no god.

\subsubsection{The a-theocracy}

Although the reigning monarch's rule displays a total disregard of God, a certain degree of allegiance to other idols does exist:

\section{Diagram 4: The a-theocracy}

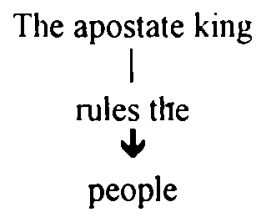

while GOD is ignored and eradicated by the apostate king as well as the elect people.

According to inter alia 2 Chronicles $21: 6-7,28: 1-4,33: 22-24,35: 5 b, 9 b, 12-13$, the Kallah month exegetes regarded certain kings as anti-Yahwistic or paganistic. It would appear as if, according to their interpretation and evaluation, all a-theocracies display two distinctive features:

- a nullification of the influence and the dictates of God,

- the total disregard of the core component elect people.

It is important that, although ruled by an apostate king, the people remain the chosen people of God dependent upon his rule. These apostate Davidites are to be held accountable for the destruction of the monarchy, the cult, the societal structures, should their repudiation of God deprive the core component, People, of their elect status as well as of their God. Without repentance and without penance 
there is punishment. On the other hand, because God, the constant core component of the theocracy, cannot be obliterated, re-election and re-creation are a certainty, even though it might even mean being exiled in a foreign country for an unknown period of time.

\subsubsection{The democracy: the rule for the people by the people}

According to their ideological exegesis of state rule, even within the purview of the theocracy, the monarchy is the preferred form of rule. However, 2 Chronicles $33: 25$ attests to the existence of a democracy within the parameters of the theocracy. The purpose of this democracy was not to replace the monarchy, but to reinstitute, to re-create the consummate monarchy a la David-Solomon.

According to 2 Chronicles 33:24 the bureaucracy of the apostate Amon executed a coup d'etat and the king died. Although the reason for the coup d'etat was the king's apostacy, the bureaucracy also sinned in its attempt to replace the preferred monarchal rule with an oligarchy. Because of the construction of the core component Elect People, the other two elements were compelled to step in and take the necessary steps to save the monarchy as well as the composition of the core component Elect People. Therefore, the cult and the non-regal and non-cultic people rallied together and in turn seized the power from the oligarchy and forned a democracy.

The institution of this democracy did not anticipate any planned change in the structure of rule. In compliance with the power vested in the inconstant theocratic core component Elect People, the urgency of the prevailing circumstances compelled the non-regal and non-cultic element to step in and to take appropriate action in order to save the element Davidic kingship and to re-institute, to recreate the theocracy. Therefore, the democracy remained functional only until the element Davidic kingship had recovered and an appropriate and a trustworthy candidate was ready to enter into the Davidic covenant in order to re-establish, to re-create and to restore the theocracy. According to 2 Chronicles 33:25 Josiah was the candidate-elect of the people.

\section{Conclusion}

The element Davidic kingship is an important example of what could be terned futuristic ideological exegesis. The historical truth is that the Southern Kingdom originated as a monarchy. The interpretive exposition of this bona fide element of the past, is that God rules his Elect People, but the crucial point is the instrument God employs at any given time to effect his rule. Because God is the constant component of the theocracy, his rule is unchangeable. However, the composite, but diversified nature and the inherent inconstancy of the core component Elect People, influence the implementation of the rule of God. Their diversified nature 
and their inherent inconstancy allow the people to accept or to reject a particular form of secular rule within the purview of the theocracy. In other words, according to this hypothesis, the core component Elect People possesses the ability, but not the right to reject the rule of God.

Furthermore, although God chose the Davidites to rule his people (1 Chr. 5:2), election does not imply instinctive fidelity. The inconstancy of the core component Elect People not only affects the manifestation of the theocracy, but it also affects the execution of the dogma of retribution which may even manifest as an exile. However, according to the interpretive portrayal of Davidic kingship as found in 1 and 2 Chronicles, exile no longer equals retribution. Exile serves to communicate the constancy of God and his infinite creative and re-creative activities in the life of the second core component of the theocracy, namely the Elect People. 2 Chronicles 36:22-23 attests to the fact that the exile failed to obliterate the Elect People. The end of the exile is therefore the beginning of a new era, but at the same time it represents the embryonic beginnings of a newly re-established and re-instituted state with the possibility of a future re-institution of the consummate theocracy a la David-Solomon, because both core components of the theocracy came intact through the exilic experience: the constant God and the inconstant people; the unchangeable, invincible God and the people, the weak link in the theocratic chain.

The debate concerning Chronicles as midrash has but just begun and at this point in time, publications concerning this topic are still virtually non-existent. However, I am of the opinion that within the foreseeable future other scholars will also venture upon this terrain and that the results should prove to be highly rewarding.

\section{Bibliography}

ALBRIGHT, W F. 1934 Light on the Jewish State in Persian Times Bulletin of the American Schools of Oriental Research, 53:20-25.

BIBLIA HEBRAICA STUTTGARTENSIA 1984. Stuttgan : Deutsche Bibelgesellschaft.

DE WETTE, W.M.L. 1806/1971. Beiträge zur Einleitung in das Alte Testament (s.l.) Olms.

FINKELSTEIN, L. 1974. The Jews Their History. 4th ed New York: Schocken

HÄNEL, J. \& ROTHSTEIN, W 1927. Kommentar zum ersten Buch der Chronik Kommentar zum Alten Testament Leipzig : (Publisher not mentioned) pp viii-xliv.

JAPHET, S. 1989a. The Supposed Common Authorship of Chronicles and Ezra-Nehemiah Investigated Anew. Vetus Testamentum, 18:330-371

JAPHET, S. 1989b. The Ideology of the Book of Chronicles and Its Place in Biblical Thought. Frankfurt : Peter Lang.

KEGLER, J. \& AUGUSTIN, M. 1984. Synopse zum Chronistischen Geschichtswerk. Frankfurt : Peter Lang.

KNIGHT, D A ed. 1990. Tradition and Theology in the Old Testament Sheffield : Sheffield Academic Press.

KRAVITZ, N 1973. 3000 Years of Hebrew Literature London : Howard \& Wyndham Ltd. 
NEL, H.W. 1989. Die Levitiese stede: Kultiese sentra of staatsadministratiewe setels? Journal for Semitics, 1 (2):257-271.

NEL, H.W. 1991. Die Kronis se uitbeelding van die teokrasie in 1 en 2 Kronieke. Pretoria : University of South Africa. (D.Litt et Phil Thesis.)

NEL, H.W. 1992. The Qahal in 1 and 2 Chronicles. (In Wessels, W. \& Scheffler, E eds., Old Testament Science and Reality. Pretoria : Verba Vitae. pp. 342-357.)

NOORDTZIJ, A. 1954. De boeken der Kronieken. Korte verklaring der Heilige Schrift met nieuwe vertaling. Volumes 1 en 2 . Kampen : J.H. Kok

O'COLLINS, G. \& FARRUGIA, E.G. 1991. A Concise Dictionary of Theology. New York Paulist Press

ROUBOS, K. 1983. I Kronieken Nijkerk: Callenbach.

TORREY, C.C. 1896. The Composition and Historical Value of Ezra-Nehemiah. Beihefie zur Zeitschrift für die Alttestamentliche Wissenschaft, 2:51-65. Giessen, Berlin.

WIFALL, W. 1974. David - Prototype of Israel's Future? Biblical Theology Bulletin, 4 (1) : 95-107, Feb. 1975.

WILLIAMSON, H.G.M. 1977. Israel in the Book of Chronicles. Cambridge : Cambridge University Press . 